\title{
A guest at the table of the gods: Religion and the origins of academic life ${ }^{1}$
}

\author{
PETER JACKSON \\ Stockholm University
}

\begin{abstract}
Proceeding from the Renaissance philosopher Giovanni Pico della Mirandola's Oration on the Dignity of Man, this paper is an attempt to survey the historical premises of the academic study of religion, both as a practice of detaching the subject matter of religion from its institutional restrictions, and as a practice of rehearsing certain modalities of thought and action (philosophical as well as religious) flourishing in the ancient world long before Christianity conquered the sphere of public worship in the fourth century. By paying particular attention to themes of suspension and commensality in religious practice and discourse, an attempt is made to reconsider the critical task of the history of religions, famously devised by Bruce Lincoln as a reversal of the orientation of religious discourse.
\end{abstract}

Keywords: Pico della Mirandola, Bruce Lincoln, cultic meals, Pythagoreanism, early Christianity, Sabians in Harran

Who would not desire, putting all human concerns behind him, holding the goods of fortune in contempt and little minding the goods of the body, thus to become, while still a denizen of earth, a guest at the table of the gods, and, drunk with the nectar of eternity, receive, while still a mortal, the gift of immortality? (Pico della Mirandola 1956 [1486], 26].)

This quotation from Giovanni Pico della Mirandola's Oration on the Dignity of Man, a statement of early humanism by an influential representative of the Italian Renaissance, brings us into the midst of things. If we are to make some historical sense of today's event, Pico's oration is the proper starting point. It is a point from which we may look back, in recognition of Pico's plea for a detached intellectual vision, on several centuries of scholastic learning in a Europe dominated by Christian doctrine and papal censorship. It is also

1 This article is based on a paper read at a conference on the current status of the history of religions in Sweden, hosted by the The Royal Swedish Academy of Letters, History and Antiquities, on 20 February 2014. Hence the reference to 'today's event' and 'a cause for academic self-examination' in the paragraphs to follow. 
a point from which we may look forward, infused by the spirit of the first privately sponsored academies, towards our own academic endeavours. Furthermore, the sense of occupying a middle ground at the intersection of two worlds can be extended from Pico's own historical situation to the position of human beings in his anthropocentric cosmology.

While still insisting that he was a devout Christian, the young Renaissance philosopher had embarked on an ambitious intellectual quest, spending seven years at Italian and French universities, immersed in the study of philosophical and theological literature from a variety of pre- and non-Christian traditions, evoking the names of ancient sages (Zoroaster, Moses, Orpheus, Hermes Trismegistos), and desiring to reveal the ultimate mysteries through immediate vision (epopteía). According to his eclectic interpretation, the human is a creature neither of heaven nor of earth, capable of transforming her or himself, and placed by God at the centre of creation:

[i]f vegetative, he will become a plant; if sensual, he will become brutish; if rational, he will reveal himself a heavenly being; if intellectual, he will be an angel and the son of God. (Pico della Mirandola 1956 [1486], 8f.)

Pico's notion of apotheosis as the reward for intellectual aspiration was not a mainstay of Christian doctrine in the fifteenth century. On the contrary, Paul and the Latin Church Fathers had developed a doctrine of faith which placed less emphasis on certain searching modes of cognizance, especially those of gnossis and curiositas, as reliable paths to divine truth. He imagines the intellectual as a guest at the table of the gods; no longer as a miserable creature doomed to fear and reverence, but as someone worthy of dignity. The commensal imagery was not an accident of classicising fancy. If anything, it deserves consideration for our current purpose of debate less as a historical subject matter in its own right than as a cause for academic selfexamination. How did we become what we are? How did we develop into the kinds of secular academics that we imagine ourselves to be when we are studying religion? In tracing the early history of academic life, I shall point to a set of ritual features and strategies that were not merely superficially linked to this way of living, but in fact strongly informed it. Before turning to this daunting task, however, let me give you a few examples of what I consider typical expressions of dissent within the contemporary field of religious studies. 


\section{Irreligious credentials}

Even the most casual visitor to a conference arranged by the IAHR or one of its member associations will perceive the tensions between loosely assembled scholarly camps. For the sake of clarity, let us think of them as teams of players involved in a prestigious game. There are rules of the game regulating general principles of conduct, but there are also styles and tactics distinguishing each team from the other, one player from another within each team, and solitary players from those associated with specific teams. Apart from a constant disagreement about preferred tactics, some players immediately disqualify themselves by breaking the general rules, either because they blatantly misinterpret the rules of the game, or because they admit that they play according to the rules of another game (i.e. religion) whose examination defines the purpose of the current game. Dogmatic theologians appear, not altogether surprisingly, as prototypes of the latter. It was in invoking this conflict of interest that the French Ministry of Education once justified its replacement of the Catholic Theological Faculties with the Fifth Section of Religious Sciences: '[W] do not wish to see the cultivation of polemics but of critical research, we wish to see the examination of texts and not the discussion of dogma.'2 Such statements of emancipation from the local sanctions of a particular religious tradition set a precedent for the current game. They forbid us to employ, for example, Pope Pius XII's encyclical Humani generis as a dictate rather than an arbitrary datum of study.

Nevertheless, the players do not find the means and ends of sidestepping dogmatic exclusivism congenial. Where some identify a genuine transcendent concern beyond the historical contingencies, others tend to historicise the mundane excuses for such a concern. In either case, however, a similar rhetoric of distance is employed to renounce the disqualifying tactics of traditional apologetics. It was apparently with the intention of nullifying this false impression of consent that Bruce Lincoln composed his now famous, almost overused, Theses on Method. ${ }^{3}$ According to Lincoln, a

\footnotetext{
2 Quoted in Smith 2013, 78.

3 Originally published in Method and Theory in the Study of Religion 8 (1996, 225-7), 'Theses on Method' was reprinted in the same journal in 2005 (17:1) alongside four critical evaluations and a response by Lincoln himself, all of which originated from sessions at the annual meetings of the Southeastern Commission for the Study of Religion and the Southeastern region of the American Academy of Religion in Atlanta on 5-7 March 2004. A critical evaluation by Tim Fitzgerald appeared in the same journal in 2006 followed by a point-by-point response from Lincoln in 2007. Apart from their recurrent appearance in MTSR, Lincoln's theses are also included in Russell McCutcheon's The Insider/Outsider Problem in Problem in the Study of Religion (McCutcheon 1999, 395-8) and as an introductory chapter in Lincoln's Gods and Demons, Priests and Scholars (Lincoln 2011).
} 
dissociation from the constraints of dogma does not fulfil the expectations of fair play. If the historical study of religion is properly to dissociate itself from its object of study, historical discourse can only justify its cause in the sharpest possible contrast to that object: 'History of religions is a discourse that resists and reverses the orientation of that discourse with which it concerns itself.' (Lincoln 1996, 225. My italics.)

Despite its wonderful economy of formulation, I hesitate to embrace this methodological dictum. My hesitance is the result of an exercise in historical scrutiny. In other words, it results from an orientation of discourse that some would consider quintessentially irreligious. Although I share Lincoln's sense of estrangement from a 'discourse whose defining characteristic is its desire to speak of things eternal and transcendent with an authority equally transcendent and eternal'(Lincoln 1996, 225), my cause for concern is rather the historical viability of the definition. For an analytical category to serve its proper purpose, it is instructive to consider why we came to use it in the way we do. In the case of religion, our preconceptions will always be hampered by the gradual reorientation of thought and practice in Late Antiquity, culminating in an unprecedented modality of absolutising religious policy. I am, of course, referring to the rise of imperial Christianity and Islam. While historians of religions have taken care not to use this new religiosity as a model for all religiosities, the former's claim to reach beyond the local, ethnic, and even imperial contexts of religion is perfectly analogous to the latter's universal definition. Hence, what Lincoln conceives as a bipolar tension between two discourses is no less a contingent state of affairs than the discourse from which he seeks refuge. A similar tension might, under different historical circumstances, furnish coexisting modalities of thought and practice with a characteristically religious tinge. Critical scholarship, if understood as an emergent epistemic technique, does not by definition distinguish itself from religion, but rather from that exceptional form of fideistic religiosity with which it once shared numerous ritual and organisational traits in contrast to those of public worship. To delineate this complex dialectic, let me start by unpacking Pico's reference to the table of the gods.

\section{Cultic meals and anti-meals in Antiquity}

Themes of commensality have informed religious practice throughout the ages. Prayers and offerings are typically modelled on the convivial sharing of food and flattery, plates and goblets passed around in a display of mutual trust, and ritual banquets arranged in order to increase the flow 
of wealth and information. The meal allows for a basic nutritional need to elicit all sorts of cultural extrapolations, ranging from mundane forms of in-group solidarity, via the creation of artificial consanguinity, to the most pretentious stagings of divine cohabitation. Notwithstanding the general pertinence of such themes, we need to acknowledge that Pico's envisioning of sublime dining also reveals the particularities of a literary past. One of the earliest literary testimonies to survive in the West, a fragment from Hesiod's Catalogue of Women, informs us:

For at that time banquets were common, and common the chairs of office to immortal gods and mortal humans.(Fragmenta Hesiodea, 1, 6-7. My translation.)

The irrevocable sense of mythical ideality is perceived here against the backdrop of a social factuality, namely animal sacrifice as the epicentre of religious life in the Greek city-state. According to the same poet, gods and mortals first 'parted' or 'had a dispute' (ekrinonto) at the ancient city of Mekone (Theogony, 535-44). The reason for the dispute was a trick played by Prometheus against Zeus during the preparation of a communal meal. By placing the edible parts of a great ox inside the animal's stomach and smearing its bones in fat, Prometheus violated a fundamental principle of hospitality. While the trick set the standard for future sacrifices, it also resulted in the human community being eternally alienated from the community of the gods. There is a clear logic at work here. Seen from below, from the perspective of quotidian human life, sacrifice anwers to the most refined form of social intercourse. Seen from above, from the imaginary vantage point of divine perfection, it instigates the transformation of a once elevated being into a greedy human subject. According to the same logic of etiquette, the moderation of the ritual subject must be further inculcated in order to restore an ideal order. This is why the poet of the Homeric Hymn to Hermes depicts the infant Hermes as a reckless cattle thief who has to emulate the oblique table manners of the Olympian gods in order to gain his stature and receive a place in their midst. That is, he has to abstain from eating the meat of Apollo's slaughtered cows while performing the sacrifice. What Prometheus did to get excluded, Hermes has to undo in order to deserve divine status. ${ }^{4}$

4 The theme of reversal is consistently evoked in the whole hymn, most glaringly perhaps in the depiction of Hermes' leading the stolen cattle backward in order to deceive his pursuer. 
It is easy to perceive the ritual meal as a distinguishing characteristic of different social networks in the ancient world. The particularities of sharing food could thus serve to encode the interests by which members of such networks were unified. At the most basic level of significance, public worship encouraged members of a local community to display rank and solidarity through elaborate games of pretence, all of which might serve to dissimulate the unthinking desire for a festive communion. Although local divinities were constantly invoked on such occasions, either in their capacities as imaginary patrons or as invisible guests of honour, this was not primarily done under some studied soteriological pretext.

At a more distinctive level of significance, however, the cultic meal was understood as a prefiguration of human insight and apotheosis. Early examples of such tendencies are the ritual prohibitions of unofficial cult societies in the late archaic period, the initiated members of which followed the permanent rules of a self-chosen 'means of living', a bios, as opposed to the locally and temporarily constrained rules of official worship (Burkert 1972, 190). The complete vegetarianism allegedly practised by some members of the Pythagorean guild, the so-called theōrētikoí, ${ }^{5}$ was clearly understood as a renunciation of the official cult of the polis (Burkert 1972, 181f.). It would, however, be misleading to consider such antinomian choices of diet as a dismissal of ritual as such. On the contrary, Pythagoreans developed their own forms of worship through severe constrictions of ritual purity (hagneîai). The whole of life was to be ritualised and subjected to a doctrine of permanent validity (Burkert 1972, 174, 190f.). Among the pronouncements of Pythagorean so-called súmbola ('passwords') or akoúsmata ('heard things') - secret maxims to which the new disciples had to listen in silence while the teacher spoke behind a curtain - a considerable number revolved around sacrificial ritual (Burkert 1972,477). They concerned what to eat and what not to eat, how to move, how to fan the fire, etc. More importantly, however, the ákousma answering the question 'What is most just?' (tí tò dikaiótaton) according to Iamblichus' De vita pythagorica was indeed, 'To sacrifice.' (thúein) (Burkert 1972, 182).

Pythagoreanism resonated with the already familiar cultic procedures of the mystery cults. The teachings of Pythagoras were conceived by his

5 The Pythagorean contribution to contemporary scholarly parlance is further highlighted by the term akríbeia, which was borrowed by modern Germanic languages (such as German [Akribie] and Dutch [acribie]), perhaps via Church Latin acribia, to signify the painstaking efforts of scholarly (especially philological) rigour. 
followers as the instructions of an initiator. ${ }^{6}$ Súmbola memorised by initiates into cultic guilds (thîāsoi) could also function as tokens of admission to a life of bliss after death. The highly formulaic so-called Orphic Gold Tablets provide a fascinating glimpse into such practices. Deposited in graves throughout the Greek-speaking world from the fifth century BCE to the second century $\mathrm{CE}$, the tablets - usually in the form of folded gold foils - are inscribed with poems addressing Bacchic initates on their final passage from life to death. Themes of divine commensality seem implicit in some of the poems, but they also give explicit instructions as to what the dead should avoid consuming. Even if parched with thirst, the initiate is instructed not to drink from the spring beside a white cypress ${ }^{7}$, but to move further ahead to the Lake of Memory. ${ }^{8}$ Furthermore, the initiate is said to be honoured with wine (tablet 26a, b), is sent by Persephone to the seats of the pure (tablet 6,7 ), becomes a god (tablet 5), and joins the thî̄asoi of the initiates (tablet 28).

The Hellenistic concept of a properly antithetical meal, the so-called antimeal, helps us to identify communities of free association in their conscious effort to withdraw from prevalent forms of social intercourse (Eckhardt 2010, 1045ff and 1060f). Philo's description in De vita contemplativa of the Jewish Therapeutae in Alexandria is stereotypically informed by such a notion. Designated as particularly attentive servants of God, the therapeutae are characterised as exemplary philosophers who arrange sacred symposia. Philo emphasises this ritual feature in order to contrast the pious activities of his protagonists with the philosophical symposia described by Plato and Xenophon (the less exemplary 'symposia of others') (40/56). We are also led to understand that the therapeutae are not merely practising any kind of Jewish worship. Men and women dine separately (69); there are no slaves (70); neither wine nor meat is consumed (85), only water, bread, salt, and aromatic leaves of hyssop (73); they prepare this 'most sacred food' and bring in the table out of reverence for (and with reference to) the sacred table set up

6 Fritz Graf paraphrasing Proclus's Theologia Platona (Graf \&Johnston 2007).

7 'Descending to it, the souls of the dead refresh themelves. Do not even approach this spring!' (Graf \& Johnston 2007, 5 [tablet 1, 4-5].)

8 ' [...] there are guards before it. / They will ask you, with astute wisdom, / what are you seeking in the darkness of murky Hades. / Say, "I am a son of Earth and the starry Sky, I am parched with thirst and am dying; but quickly grant me / cold water from the Lake of Memory to drink." / And they will announce you to the Cthonian King, and they will grant you to drink from the Lake of Memory. / And you, too, having drunk, will go along the sacred road on which other / glorious initiates and bacchoi travel.'(Graf \& Johnston 2013, 5 [ tablet 1,7-16].) 
in the the entrance hall of the temple in Jerusalem (81). The familiar pagan notion of the thîasos allows Philo to engage in a double-acting rhetoric. He means to persuade his reader that the Jewish therapeutae, while remaining true to their own traditions, are in fact actively living the moderate life about which 'the other' (i.e. gentile) philosophers have only been talking. ${ }^{9}$

Greek philosophy certainly had its active share in this rhetoric, for it was along similar lines of confabulation that Theophrastus, a successor of Aristotle, described the Jews as a people of philosophers. They are said not to feast on the flesh of sacrificed animals, but to burn them whole (holokautoûntes) during the night. They fast for the intervening days, converse with each other about the deity, and immerse themselves in the theory of stars (ástrôn poioûntai tên theōrían). Contrary to Philo, however, Theophrastus concludes that the Jews behave like this under compulsion and not from their own free will. ${ }^{10}$

Nothing prevents us from recognising the sacrificial exigencies of public worship, and the unofficial anti-meal of the thîāsos, as being equally ritualistic in the sense that they are extrapolations of the daily meal. However, whereas the former distinguished itself from everyday meals through excess and hyperbole, the latter did so through deficit and suspension of judgement. Encoded into the latter form of social intercourse was not an upheaval of sacrifice, but rather a perfection and sublation of the whole ritual apparatus. Attentiveness was no longer considered a precautionary measure in a temporary cultic setting, but a means of transforming onself into something else, of changing one's way of looking at the world..$^{11}$ Although the specific means and ends of such spiritual excercises would differ greatly, the attitude of the initiate was typically considered a matter of life and death

\footnotetext{
9 We need to keep this scenario in mind when we consider why Paul, in his First Letter to the Corinthians (11 33-34), warns the parishioners to visit the Lord's supper on an empty stomach: 'So then, my brothers and sisters, when you come together to eat, wait for one another. If you are hungry, eat at home, so that when you come together, it will not be for your condemnation.'

10 Theophrastus quoted in Porphyry's De abstinentia (2,26) (Stroumsa 2009, 60). Cf. the conflicting view in Philo's De vita contemplativa (71).

11 The notion of the human subject's care and transformation of itself in ancient philosophy is a recurrent topic in the late writings of Michel Foucault, who also devoted one of his last courses at the Collège de France to its exposition posthumusly published under the title L'herménetique du sujet (Foucault 2001). Focault had been largely influenced by the historian of philosophy Pierre Hadot (1995), whose late work Qu'est-ce que la philosophie antique? concisely delineates the central ideas. Guy Stroumsa's La fin du sacrifice: Le mutation religeuses de l'antiquité tardive (Paris: Odile, 2005) (translated into English as Stroumsa 2009) further develops the notion of spiritual transformation and its impact on sacrificial ideology in Late Antiquity.
} 
to the same extent as it was taken up with a singular point of stable reference. At the expense of immediate needs and local obligations, even to the point of becoming an object of ridicule and public accusation, the subject of the self-chosen bios relied insistently on the delayed payback of insight and salvation. ${ }^{12}$ Before the large-scale, imperial conversion to a singular bíos, religious behaviour had thrived in a perceived tension between two poles, both of which exhibited recognisably religious traits; two religiosities vacillating between local games of momentary pretence and permanently universalising strategies of self-transformation. Although the dichotomisation is somewhat simplistic, we may need to maintain it in order to clarify a considerably more distorted view.

\section{The secret life of the academy}

A new sense of contrast between Christianity and pagan religiosity had, from the late fourth century onwards, through the decrees of the converted emperors, gradually erased a previous contrast between public worship and the rites of the thîāsos. When allegiance to the exclusive latter was no longer considered a private matter, the public claims of the former became enmeshed in the soteriological claims of the latter. Public worship and personal faith were now considered indistinguishable aspects of piety, whereas the presence of an autonomous intellectual laity posed a constant threat to an ecclesiastical regime of truth. ${ }^{13}$ One way of pin-pointing this castling move of religious policy is to analyse the changing iconography of intellectuals in Late Antiquity.

In a groundbreaking study from 1995 Paul Zanker demonstrated how the iconic representation of the philosopher - typically male, bearded and

12 One of the most tenacious allegorisations of this dilemma is the story of the philosopher qua astronomer who falls into a well while studying the stars. Hans Blumenberg's (1987) perceptive exploration of the fable's repercussions in Western thought, Das Lachen der Thrakerin: Eine Urgeschichte der Theorie, initially (13f.) highlights the importance of conflicting perspectives in the plot: the exploratory gaze of the philosopher and the condescending gaze of the Thracian maid. These conflicting perspectives, both easilly recognisable to anyone involved in the less pragmatic endeavours of scholarship and science, imply a reversal of the expected power relations. She, the low-cast woman from a foreign country, now speaks with the authority of the polis, whereas he, the nobleman from the ancient city, has abandonded his civil duties and turned his attention to a foreign cause. Under his scrutiny she recognises no domestic divinities. They exist only where he falls into the well. For this reason, her malicious joy is fully justified and attuned to the interests of the city.

13 Cf. especially Stroumsa's discussion of the inversion of the pairs sacred/profane and public/private (Stroumsa 2009, 90f.). 
long-haired, sorrounded by muses and disciples, carrying book rolls and codices, etc. - was subjected to a far-reaching artistic re-evaluation in Late Antiquity (Zanker 1995). ${ }^{14}$ The image of Christ and his followers was inserted into a familiar pictorial formula to make Christian teachings appear as the continuation of a long and respectable tradition of philosophical learning. Even in portrayals of miracles, Christ himself, the apostles, and saints seem to emulate the appearance of pagan intellectuals. This was apparently not just a superficial strategy of visual imagery, for influential Christians explicitly encouraged each other to adopt this appearance in their daily lives. Tertullian composed a whole speech 'On the mantle' (De pallio), in which he encouraged his brethren to start wearing the typical outfit of philosophers (the so-called pallium) in a consciously counter-cultural spirit (Zanker 1995, 290-3). ${ }^{15}$ In a similar vein Clement of Alexandria wrote in favour of the beard 'on the grounds that it gives a man a dignified and awe-inspiring appearance'. ${ }^{16}$

In structural response to the encryption and transmutation of pagan philosophy in early Christian theology, the antithetical iconography of the 'new philosophy' encrypts and inverts the image of the pagan intellectual. Zanker posits a particularly compelling argument in this regard towards the end of his final chapter ('The Power of the Muses'). Hellenistic philosophers were aware of the idea that all intellectual activity, even in its capacity as a corollary of human volition, was only possible through a form of divine dispensation. To think truthfully and creatively, using one's own critical intellect, still implied the service of divine creatures. One class of beings to inhabit this theoretical space was the Muses, the daughters of Zeus and Mnemosyne, who had long been considered sources of poetic inspiration. In their role as handmaidens of the poet or philosopher they did not force themselves upon their master. Zanker even points to a Roman votive relief portraying the Muse as respectfully looking up at the poet just 'as a schoolgirl to her teacher.' (Zanker 1995, 328) Through her transposition into the Christian iconography of Holy Writ, however, the female companion of the bearded man is transformed into an authorising monitor. A case in point is an illustration in the sixth century Rossano Gospels. Saint Mark is shown seated, writing the Gospel, while a standing female figure traces his text with her finger:

14 See especially ch. VI (The Cult of Learning Tranfigured).

15 Tertullian ends his speech by exclaiming (De Pallio, 6,4): 'Rejoice, pallium, and exult! A better philosophy has deigned you worthy, from the moment that it is the Christian whom you started to dress.'

16 Paedagogus $(3,11,60)$ paraphrased in Zanker 1995, 290. 
[A] female personification - or is she an angel without wings? - has taken the place of the Muse and dictates word for word to Saint Mark, even going over with her finger and checking what he has just written. The concept of the transmission of knowledge will from now on be dominated by such images of authority. The medieval teacher sits or stands elevated above his pupils and dictates to them. (Zanker 1995, 330)

We can see here an example of what Lincoln would immediately recognise as a discursive inclination to - as he might be paraphrased - write of things eternal and transcendent under the equally transcendent and eternal authority of God. Saint Mark is clearly not depicted as a free intellectual, straining his critical faculties in order to reach the indeterminate solution to a puzzle. Nevertheless, he has borrowed some unmistakeable characteristics of the intellectual, superficially pretending to be the kind of bookish, bearded scholar that his informed viewer knows him not to be.

Since the teachings of Christ were so persistently hailed by their early supporters as an exclusive corrective to pagan philosophy, despite the latter's obvious yet encrypted inclusion in those teachings, we are not suprisingly led to consider critical scholarship as a corrective to that view. This should not, however, lead us to equate a specifically Christian outlook with any religious modality. However, attempts at tracing the origins of Greek philosophy are characteristically informed by the notion that the first philosophically valid statements were formally restricted to, and ultimately obstructed by, a discourse permeated by myth and epic. ${ }^{17}$ According to this distorted view, the delusion of myth defines the essence of religion (the inferior yet imputed 'theory') from which the philosopher seeks to detach himself by means of inference and pure reason. Representing the tension between early philosophy and religion in such terms is anachronistic. It results from a regressive formation of myth as an article of faith. It would be more accurate to assume that pagan religiosity reaches us through philosophy, with distorted hindsight, as a corrective to fideistic religiosity.

We need to recall the fact that some of the pagan sites of worship targeted by the early imperial church were also centres of learning. The academy in

17 The following statement by Hans-Georg Gadamer (Gadamer 1993, 130) symptomatically evokes this view: '[...] die von Homer und Hesiod ausgehende große epische Überlieferung, [hat] trotz ihrer mythischen und erzählenden Form, philosophischen Wert [...] Daß zwischen episch-religiöser Sicht und begrifflichem Denken ein enger zusammenhang bestehen kann, liegt auf der Hand. Zu einer Zäsur gelangen wir erst bei Platon, und zwar dann, wenn es als besonders kennzeichendes Merkmal seiner Vorgänger hinstellt, daß sie Märchen erzählt haben.' 
Athens, which we shall consider soon, bore all the hallmarks of a religious institution, of a thîāsos (Athanassiadi 2004, 213). Another example is the Serapaeum in Alexandria.

According to the historian Sozomen's fifth century account of civil skirmishes in Alexandria occasioned by the emperor's intensified promulgation of decrees against pagan worship in 391, a man named Olympius is said to have joined a crowd of disheartened pagans (simply referred to as 'Greeks' [Héllenes]) inside the temple of Serapis. $(1984,7,15$.$) The crowd$ had barricaded itself into the temple after a series of retributions for the local bishop's exposure and ridicule of sacred objects concealed inside a temple of Dionysos. Olympius tries to heighten the spirit of resistance, insisting that it is better to die before renouncing the ancient customs. With an apparent effort to efface the fear of death among his fellow pagans, he evokes the desecration of their statues. While the statues are mere appearances made of perishable matter, he maintains that the powers that inhabit them have gone to heaven. It is a significant detail in Sozomen's portrayal of the agitator that Olympius is said to have joined the other pagans 'in the appearance of a philosopher' (en philosóphou skhêmati). Although Sozomen is clearly employing a familiar ironic formula, suggesting that Olympius was merely a fake philosopher, it is evident from other sources (such as the 10th century Byzantine encyclopedia commonly refered to as the Suda) that Olympius was indeed a Neoplatonist of Cilician origin who had arrived in Alexandria to serve as a priest in the cult of Serapis. His role in the account is thus characteristic of the part played by Neoplatonists in the resistance against Christians during the third and fourth centuries. Another prominent figure in that struggle was the philosopher and mathematician Hypatia. Having survived the skirmishes in 391, she was eventually put to death by a Christian mob in 415. It should be emphasised, furthermore, that the Serapeum in Alexandria had long served as a prestigious seat of learning, containing within its walls a court; temples of Serapis, Isis, and Anubis; a library; an incubation hall; and a priestly dormitory. ${ }^{18}$

According to a still widespread opinion, the last branch of Neoplatonism to remain uninfluenced by the official Christianisation of the Roman Empire was finally broken in the first half of the sixth century. Emperor Justinian, who had used different legislative means to suppress both paganism and heterodox Christianity in the Byzantine Empire, issued a decree in 529 to instigate the closing of the Platonic Academy in Athens. Justin-

18 Cf. Laurent Angliviel de la Beaumelle's and Guy Sabbah's annotations to Sozomen's Historia ecclesiastica $(2008,136 f)$. 
ian's religious policy is usually considered to have been a catalyst for the school's last pagan philosophers - Damascius, Simplicius, and a few of their companions - to take refuge in the Sasanian court, from which they were permitted to return three years later. ${ }^{19}$ Due to the great uncertainty concerning the group's ongoing fate and whereabouts, the closing of the Academy is often considered the death blow to paganism in the Byzantine Empire. While a chain of transmission seems to be broken at this point, we are left with an enigmatic gap in the transmission of Greek philosophy to the Arabs some centuries later.

Michel Tardieu (1986) proposed a fascinating solution to this puzzle. Proceeding from earlier research into a mysterious group referred to in the Quran as Sabians (sāabi'ūn, șa $\left.\bar{a} i^{\prime} a\right)$, and to a group with the same name known from later sources to have inhabited the city of Harran in southeastern Anatolia, Tardieu develops the hypothesis that the Arabic term șābi' could roughly correspond to the broad sense of the term hélle, i.e. 'Greek' or 'pagan'. He argues that a so-called mağma' ('gathering place') in Harran - described by the travelling Muslim historian al-Mas 'ūdī in the tenth century - was in fact a Platonic Academy, the activities of which had begun in the sixth century when it was to provide a new haven for Simplicius and the other exiles of Athens. Although Tardieu's hypothesis remains a matter of scholarly dispute, we need not wholeheartedly subscribe to it in order to appreciate al-Mas 'ūdī's eyewitness account of the Sabians in Harran.

What unfolds before us here is nothing less than a projection of the divided pagan community that one would have expected to be but a distant memory in the Levant by the tenth century. Al-Mas'ūdì divides the Harranians into two categories: the 'philosophers' (hašwiyya), the vulgar adherents to the pagan religion of the city, and the 'sages', in the strict sense of the term. The vulgar pagans practise divination, make animal sacrifices to local divinities (the foremost among whom is Šamāl), and celebrate ensuing cultic meals in their temple. The 'sages', on the other hand, avoid such sacrificial and divinatory practices, with the exception of 'mysterious and secret ceremonies'. Their mağma 'is a gathering place for intellectuals (Tardieu 1986, 17ff.). Its door knob bears an Aramaic inscription - a veritable invitation to the bios philosophikós - which can be traced, via Neoplatonic expositions of the Platonic dialogue First Alcibades (133c), to the Socratic precept of self-examination. Part of the inscription contains a maxim. It is explained to al-Mas 'ūdī by a certain Mālik ibn 'Uqbūn, who is probably the

19 The details of the story remain a matter of some controversy. For a critical discussion, cf. especially Erhart 1998. 
leader of the sages in Harran: 'He who knows his own nature will become divine.' (Tardieu 1986, 13, 16)

The school in Harran functioned like all schools of philosophy. It had its own programmes and rituals. The tasks of its members included reading and interpreting texts, translating, and producing commentaries. But the mağma' of Mālik ibn 'Uqbūn was also an institution passing on a pagan tradition of apotheosis and critical self-fulfilment.

When the urban community of Sabians in Harran was extinguished about a century after al-Mas 'ùdì's visit to the city, important aspects of their style of scholarship had already been passed on to other centres of learning in the Islamic world, not least to Baghdad. ${ }^{20}$ However, the triangular scheme evoked by al-Mas 'ūdī's unique testimony - two coexiting modalities of paganism (a religion of the bios, and that of a local civic cummunity) supervised by a Muslim historian from the third angle of the caliphate - was bound to become distorted. It is within this fractured space that adherents of the bíos akadèmikós begin their new journey towards a perceived position outside the sphere of religion. A decisive move in that direction was made when Cossimo de' Medici, only four centuries later, decided to sponsor the activities of a so-called Platonic Academy in Florence. Led by Marsillio Ficino, it counted among its members the young Pico della Mirandola, and stimulated the emergence of similarly autonomous thîāsoi in the West through the reintroduction of Neoplatonism. The old-school pagan intellectual was about to return. ${ }^{21}$

20 Not least through Tabit ibn Qurra (835-901), who had moved from Harran to Baghdad to found a new Sabian community there under the protection of the caliph al-Mu'tadi. 21 The transmission of Neoplatonism to the Western world in the 15th century is currently a focal concern in the study of Western esoteriscism. A key figure in this process was the Byzantine philosopher Gemistos Plethon (1355-c.1452), who also played an important role at the ecumenical Council of Florence. Gemistos had, in his turn, been influenced by a mysterious man called Elissaeus (Elisha) in an Ottoman environment, perhaps in the city of Bursa. Elissaeus is said to have been sent into exile ('in barbarian territory') from Constantinople, and is described in a letter by the Patriarch Scholarius as 'ostensibly a Jew but in fact a Hellenist [pagan]' and 'an adherent of Averroes and other Persian and Arabic interpreters of Aristotle's works'. (Woodhouse 1986, 24). Scholarius complains in the same letter that Gemistos 'was so dominated by Hellenic ideas that he took little trouble about learning traditional Chrstianity, apart from the most superficial aspects. In reality it was not for the sake of the Greek language, like all Christians, that he read and studied Greek literature [...] but in order to associate himself with them.' (Woodhouse 1986, 24). For a comprehensive treatment of these issues in the wider context of Western academic culture, see Hanegraaf 2012, 33f. Cf. also Hladky' 2014, 191ff. 


\section{Conclusions}

I have chosen a meandering detour in my attempt to readdress the issue of religion and the humanities, of religion within or without the humanities. Before making some concluding remarks in this regard, let me summarise what I consider to be the most salient basis of religious behaviour beyond its superficial restriction to a permanent belief in.

Despite the occasional insistence on unconditional faith, religious participation can be widely attested as the result of a voluntary and momentary disposition of mind. We may affirm beliefs by acting as if believing what is conceived not to be true, or we may place something under scrutiny by acting as if not knowing what is conceived to be true according to immediate judgement. ${ }^{22} \mathrm{~A}$ juxtaposition of these frames of mind should make clear how they differ, but also how they are united by a reluctance to accept indisposed preconceptions. If the suspension of disbelief implies a disposition towards artificiality (or so-called apparatuses), the suspension of judgement implies a disposition towards indeterminacy. While such voluntary dispositions of mind may come into conflict, they may also coexist within the same ritual framework. Take, for example, the case of Graeco-Roman animal sacrifice: the first attitude (suspension of disbelief) ensures the acceptance of circumstances that are not intuitively apparent (e.g. the conjuring of animal consent and divine participation), whereas the second (suspension of judgement) ensures a submission to arational processes (e.g. inspecting the sacrificial animal's entrails in order to receive an indeterminate reply).

The latter sense of inculcated attention is certainly not foreign to the practice of critical scholarship. Herodotus came close to formulating a divinatory principle of suspended judgement when, at the beginning of his Histories, he claimed to be obliged to say what had been said (egô opheílô légein tà legómena $[7,152,3]$ ) about the Persian wars, despite his strong opinions as to who had done wrong to the Greeks $(1,5)$. It was apparently in a similar vein that Friedrich von Schlegel, in one of his Athenaeum Fragments (80), famously characterised the historian as 'a prophet facing backwards' (ein rückwärts gekehrter Prophet) (Schlegel 1967 [1798], 176).

The purportedly religious traces of scholarship should not be exaggerated, but it would be no less an exaggeration to reduce these traces to obsolete paraphernalia and empty modes of ceremonial parlance. While I am aware of the scholarly efforts to avoid bias and subservience, I am not trying to discredit these efforts in a nagging spirit of relativism. I am, how-

22 Regarding the concept of 'as if-ness', cf. Benavides 2010, 239-253. 
ever, concerned about the tendency to over-determine the notion of religious practice as a proto-political cover-up, and even as a misinformed groping in the dark, for which critical scholarship provides the ultimate cure. For the sake of theoretical utility, I do not hold religion to be all about effectuating interests through uncritical compliance, nor do I find any historical justification for its reduction to a theory of the world, from which the scholar seeks to detach her or himself by means of pure reason. In stressing this, I am not morally concerned about religion, believing it to have been unduly discredited as an undifferentiated whole. I consider myself neither a caretaker nor a transcendentalist. I simply want to acknowledge the multimodal character of this human propensity as a necessary clue to its historical raison d'être.

We should not disregard the fact that we, as members of the academy, still maintain specific communal concerns by arranging symposia and round tables, by engaging in what we know as disciplinary practice, and by imagining that such forms of ritualised behaviour foster a sense of truth and reality beyond the premature bounds of our immediate judgement. The communal sharing of food and ideas is perhaps the most glaring example of a social event neutralising the objective what and the methodological how of our academic aspirations. There is more than a trivial affinity between what we, as students of religion, concern ourselves with and how we consider these concerns to demand certain ingrained standards of etiquette.

It does not seem entirely out of place to regard contemporary scholars of the humanities as the distant heirs of figures such as Simplicius, Mālik ibn 'Uqbūn, and Pico della Mirandola. All of them led the kind of examined life that many worried intellectuals now believe to be facing a crisis of immense proportions (Nussbaum 2010). If humanist knowledge is only justified in terms of its servitude to some predefined aspect of public life, it will never expose us to the value of life itself, nor will it encourage us to historicise that particular kind of knowledge in order to reach beyond it. It was precisely for this reason that Socrates defined the examined life as the only life worth living. ${ }^{23} \mathrm{He}$ did so in a spirit of civil disobedience, in opposition to a more short-sighted gain in the sphere of public interest, and it is precisely for these reasons that the task of the humanities seems so precious in our time. When Pico, with an undeniable nod to the Socratic ideal, imagines intellectual life as an invitation to a life in the company of gods, we need to pay particular attention to the concept of divinity inherent in this notion. For any exponent of the works of Plato, the most familiar characterisation of intellectual con-

23 'The unexamined life is not worth living for a human being' (ho dè anexétastos bíos ou biōtòs anthrôpōi [Apology, 38a]). My translation. 
templation would be that of the the mind's ascent to knowledge of divine forms. According to this concept, furthermore, divine forms have nothing to do with the fabulous creatures of myth. Instead, they are the means of conceptualising an ideal reality - including, for instance, the objects and structures of mathematics - independent of human artifice and persuasion.

Walter Capps once remarked that 'religious studies may have created a phenomenon against which it has been judiciously trying to distinguish itself.' (Smith 2013,73) I am uncomfortable with this rhetoric of contagion, although not, of course, as long as Capps's distinction merely signifies the distance required to establish anything as an object of scientific knowledge, which would indeed be a sound but somewhat trivial point to make. What concerns me is rather the rhetorical incentive to reduce religion to the impoverished, credulous, and superstitious affair that traditional apologetics have always disqualified as falsa religio, as the religion of others. A modern (or modernist) approach to reality in its scientifically grounded version of preconceived reality, i.e. a reality that runs short of everything that religious people consider supernatural, entails a vague and distorted echo of a pagan approach to the divine. What the pagan philosophers once considered traceable as divine reality through disciplined means of cognizance, the moderns now conceptualise as natural as opposed to a Christian appropriation of untraceable divinity. It all seems to end and begin with Shakespeare, whose contribution to the understanding of Western modernity appears quintessential. In the play All's Well That Ends Well he combines two cornerstones of our contemporary condition (modern and supernatural) as he has old Lord Lafew utter the following words (Act 2, Scene 3):

They say that miracles are past, and we have our philosophical persons, to make modern and familiar, things supernatural and causeless. Hence is it that we make trifles of terrors, ensconcing ourselves into seeming knowledge, when we should submit ourselves to an unknown fear.

PETER JACKSON is Professor of History of religions at Stockholm University, Sweden.

E-mail: peter.jackson@rel.su.se 
Bibliography

Primary sources

Homeric Hymns

1936 T. W. Allen \& W. R. Halliday \& E. E. Sikes (eds) The Homeric Hymns. 2nd ed. Oxford: Clarendon Press. (Oxford Classical Texts.)

Herodotos Histories

1997 Haiim B. Rosén (ed.) Herodoti Historiae Vol. II, libros V-IX continens. Leipzig: Teubner.

Hesiod Catalogue of Women

1967 Reinhold Merkelbach \& Martin L. West (eds) Fragmenta Hesiodea. Oxford: Clarendon Press.

Hesiod Theogony

1966 Martin West (ed.) Theogony. Oxford: Clarendon Press.

Philo De vita contemplativa

1963 F. Daumas \& P. Miquel (eds and trans.) De vita contemplativa. Paris: Éditions du Cerf.

Plato First Alcibiades

1901 Burnet, John (ed.) Platonis opera. Vol. II. Oxford: Clarendon Press.

Sozomen Historia ecclesiastica

1984 Joseph Bidez (ed.), Sozomenus Kirchengeschichte. Berlin: Akademie Verlag.

2008 Laurent de la Baumelle et al. (eds and trans.) Histoire ecclésiastique, livres VI-IX. Paris: Éditions du Cerf. (Sources chrétiennes 516.)

Tertullian De Pallio

2005 Vincent Hunink (ed. and trans.) De Pallio. Amsterdam: J. C. Gieben.

Secondary sources

\section{Athanassiadi, Polymnia}

2004 Heroization, Apotheosis (3.d.) IV. Ascent to heroic or divine status in antiquity: continuities and transformations - Thesaurus Cultus et Rituum Antiquorum (ThesCRA) Vassilis Lambrinoudakis et al. (eds). Vol. II, 212-14. Los Angeles: The J. Paul Getty Museum.

\section{Benavides, Gustavo}

2010 On the Production of Religious Configurations - Method and Theory in the Study of Religion 22, 239-53. 


\section{Blumenberg, Hans}

1987 Das Lachen der Thrakerin: Eine Urgeschichte der Theorie. Berlin: Suhrkamp.

\section{Burkert, Walter}

1972 Lore and Science in Ancient Pythagoreanism. Cambridge, Mass.: Harvard University Press.

\section{Eckhardt, Benedikt}

2010 Mahl V (Kultmahl) - Reallexikon für Antike und Christentum, Georg Schöllingen et al. (eds) Vol. XXIII, 1012-1105. Stuttgart: Anton Hiersemann

\section{Erhart, Victoria}

1998 The Context and Contents of Priscianus of Lydia's Solutionum ad Chosoroem. Medieval Philosophy. Papers presented at the Twentieth World Congress of Philosophy in Boston, Massachusetts, August 10-15, 1998. <http://www.bu.edu/wcp/MainMedi.htm>, accessed 1 December 2015.

\section{Fitzgerald, Tim}

2006 Bruce Lincoln's 'Theses on Method': Antitheses - Method and Theory in the Study of Religion18, 392-423.

\section{Foucault, Michel}

2001 L'herménetique du sujet. Paris: Seuil/Gallimard.

\section{Gadamer, Hans Georg}

1993 Der Anfang der Philosphie. Stuttgart: Philipp Reclam jun.

\section{Graf, Fritz \& Sarah Iles Johnston}

2007 Ritual Texts for the Afterlife: Orpheus and the Bacchic Gold Tablets. London/ New York: Routledge.

\section{Hadot, Pierre}

1995 Qu'est-ce que la philosophie antique? Paris: Gallimard.

\section{Hanegraaf, Wouter J.}

2012 Esotericism and the Academy: Rejected Knowledge in Western Culture. Cambridge: Cambridge University Press.

\section{Hladký, Vojtěch}

2014 The Philosophy of Gemistos Plethon: Platonism in Late Byzantium, Between Hellenism and Orthodoxy. Surrey: Ashgate.

\section{Lincoln, Bruce}

1996 Theses on Method - Method and Theory in the Study of Religion 8, 225-7. 2007 Consessions, Confessions, Clarifications: By Way of Response to Tim Fitzgerald - Method and Theory in the Study of Religion 19, 163-8. 
2011 Gods and Demons, Priests and Scholars. Chicago: Chicago University Press.

\section{McCutcheon (ed.)}

1999 The Insider/Outsider Problem in the Study of Religion. Londonand New York: Cassel.

\section{Nussbaum, Martha}

2010 Not for Profit: Why Democracy Needs the Humanities. Princeton and Oxford: Princeton University Press.

Pico della Mirandola, Giovanni

1956 Oration on the Dignity of Man (1486). Translated by A. Robert Caponigri. Washington, D.C.: Regnery Publishing, Inc..

\section{von Schlegel, Friedrich August Wilhelm}

1967 Kritische Friedrich-Schlegel-Ausgabe. Ernst Behler et al. (eds). Vol. II. Paderborn: Fridinand Schöningh Verlag.

\section{Shakespeare, William}

1623 All's Well, that Ends Well - Comedies, Histories, E Tragedies. Published according to the True Original Copies. London: Isaac Jaggard and Edward Blount.

\section{Smith, Jonathan Z.}

2013 On Teaching Religion. Oxford: Oxford University Press.

\section{Stroumsa, Guy}

2009 The End of Sacrifice: Religious Transformations in Late Antiquity. Chicago and London: Chicago University Press.

\section{Tardieu, Michel}

1986 Sạabiens coraniques et 'Sạabiens' de Hạrān - Journal asiatique 274, 1-44.

\section{Woodhouse, C. M.}

1986 Gemistos Plethon: The Last of the Hellenes. Oxford: Clarendon Press.

\section{Zanker, Paul}

1995 The Mask of Socrates: The Image of the Intellectual in Antiquity. Berkeley/ Los Angeles/Oxford: University of California Press. 